\title{
Scenariusze dostosowawcze sektora ekonomii społecznej do realiów czwartej rewolucji przemysłowej $^{1}$
}

\author{
Marcin Zawicki*
}

\begin{abstract}
Streszczenie: Czwarta rewolucja przemysłowa wywołuje głębokie zmiany w każdym sektorze gospodarki i w społeczeństwie. Jej skutki będą też odczuwalne przez podmioty ekonomii społecznej. Celem artykułu jest nakreślenie scenariuszy określających stopień dostosowania się organizacji ekonomii społecznej w Europie do przemian technologicznych dokonujących się w ramach czwartej rewolucji przemysłowej. Na podstawie studiów literaturowych oraz heurystycznej metody scenariuszowej sformułowano trzy scenariusze dostosowawcze podmiotów ekonomii społecznej do nowych realiów - reaktywny, adaptacyjny i antycypacyjny. Realizacja określonych scenariuszy będzie miała wpływ na przyszłość każdego podmiotu ekonomii społecznej, jak i całego sektora.
\end{abstract}

Słowa kluczowe: czwarta rewolucja przemysłowa, ekonomia społeczna, scenariusze rozwoju, polityka publiczna.

\section{Wprowadzenie}

Czwarta rewolucja przemysłowa, nazywana także Przemysłem 4.0, nabiera rozpędu. Jej skutki nie są jeszcze dobrze rozpoznane, ale na pewno wpłynie ona na wiele aspektów życia jednostek ludzkich i wszystkie formy ich zbiorowych aktywności.

Celem artykułu jest nakreślenie scenariuszy określających stopień dostosowania się organizacji ekonomii społecznej w Europie do przemian technologicznych dokonujących się w ramach czwartej rewolucji przemysłowej.

Publikacja została przygotowana w projekcie „Ekonomiczna analiza marginalizacji własności w gospodarce" nr: 056/ WGAP-KAP/01/2018/S/8056, dofinansowanym z dotacji Ministerstwa Nauki i Szkolnictwa Wyższego dla Wydziału Gospodarki i Administracji Publicznej Uniwersytetu Ekonomicznego w Krakowie na utrzymanie potencjału badawczego.

\section{Natura i siły napędowe czwartej rewolucji przemysłowej}

Rewolucja przemysłowa nie posiada jednoznacznie określonego zbioru desygnatów, które ją konstytuują [Maynard, 2015]. Zazwyczaj utożsamia się ją z rewolucją technologiczną i jej skutkami oraz opisuje za pomocą przełomowych technologii, które gruntownie przekształcają istniejące praktyki gospodarcze. Takiemu podejściu odpowiada charakterystyka trzech poprzednich rewolucji przemysłowych, których istota polegała odpowiednio na: (1) Mechanizacji - wprowadzaniu mechanicznych urządzeń produkcyjnych napędzanych wodą i parą wodną; (2) Elektryfikacji - wdrażaniu technologii produkcji masowej opartej na energii elektrycznej oraz na podziale pracy; oraz (3) Cyfryzacji - zastoso-

\footnotetext{
* Marcin Zawicki

Katedra Administracji Publicznej Uniwersytet Ekonomiczny w Krakowie ul. Rakowicka 16, 31-510 Kraków e-mail:zawickim@uek.krakow.pl
} 
waniu elektroniki i technologii informacyjnych w dalszej automatyzacji procesów wytwórczych [Drath, Horch, 2014].

Mottem czwartej rewolucji przemysłowej stają się systemy cybernetyczno-fizyczne [Liao et al., 2017, s. 3609; Buhr, 2015, s. 5], łączące w procesach pracy systemy komputerowe, oprogramowanie i ludzi [Baldassari, Roux, 2017, s. 20]. Przykładami takich systemów są samouczące się roboty, technologie konserwacji zapobiegawczej, samoczynnie rekonfigurujące się maszyny oraz inteligentne technologie ochrony środowiska [Brekelmans, 2016].

Wyróżnikami czwartej rewolucji przemysłowej są ponadto: postępująca automatyzacja procesów wytwórczych i usługowych, rozwój technologii bazującej na sztucznej inteligencji i samouczeniu się maszyn, miniaturowych i mocnych czujnikach wykorzystywanych do gromadzenia różnorodnych informacji oraz przetwarzających je superkomputerach, a także powszechnie dostępny Internet. Rewolucja będzie następowała w przestrzeni fizycznej (pojazdy autonomiczne, druk 3D, nowe materiały, zaawansowane roboty), cyfrowej (Internet rzeczy, systemy cybernetyczno-fizyczne) oraz biologicznej (inżynieria i sekwencjonowanie genetyczne, biologia syntetyczna i edytowanie genomów) [Kuruczleki et al., 2016, s. 329, Buhr, 2015, s. 8].

Nowe rozwiązania technologiczne przyspieszają zastępowanie produkcji masowej produkcją spersonalizowaną oraz prowadzą do obniżenia kosztochłonności i zwiększenia efektywności wykorzystywanych zasobów. Poza radykalnymi zmianami procesów produkcyjnych i modeli biznesowych, czwarta rewolucja przemysłowa rekonfiguruje rynki usługowe i konsumenckie, infrastrukturę techniczną i praktyki zarządzania publicznego ${ }^{2}$. Na płynnych rynkach pracy upowszechniają się elastyczne formy zatrudnienia, wzrasta mobilność pracowników oraz polepsza się dopa-

Administracyjny wymiar czwartej rewolucji przemysłowej określany jest mianem Rządu 4.0. sowanie pracy. Ogół tych zmian gruntownie przebudowuje uczestnictwo człowieka w procesach gospodarczych. Jak trafnie spostrzega M. Csath [2018, s. 65], te w istocie mega-zmiany nie redefiniują wyłącznie technologii, lecz przede wszystkim społeczeństwo jako całość ${ }^{3}$.

Eksperci McKinsey Global Institute szacują ${ }^{4}$, że w najbliższych latach czwarta rewolucja przemysłowa spowoduje wzrost zapotrzebowania na prace wykonywane w takich grupach zawodowych, jak: dostawcy usług opiekuńczych ${ }^{5}$, nauczyciele i trenerzy ${ }^{6}$, menedżerowie i kierownicy ${ }^{7}$, specjaliści ${ }^{8}$, specjaliści ds. technologii ${ }^{9}$, pracownicy branży kreatywnej ${ }^{10}$, pracownicy branży budowlanej ${ }^{11}$. Na zbliżonym do obecnego poziomu powinien się utrzymywać popyt na pracę w grupach zawodowych, których praca polega na interakcji z interesariuszami ${ }^{12}$ oraz osób pracujących w nieprzewidywalnym otoczeniu ${ }^{13}$. Na największe ryzyko utraty pracy są natomiast narażeni pracownicy biurowi ${ }^{14}$ oraz osoby wykonujący prace $\mathrm{w}$ przewidywalnym otoczeniu $^{15}$ [Manyika et al., 2017, s. 10]. Czynności wykonywane przez dwie ostatnie grupy

\footnotetext{
Przemiany te opisuje termin Społeczeństwa 4.0.

Badania przeprowadzono na próbie sześciu czołowych i rosnących gospodarek światowych: Chin, Indii, Japonii, Meksyku, Niemiec i Stanów Zjednoczonych.

Lekarze, pielęgniarki, domowa opieka medyczna, opiekunowie dzieci, pracownicy socjalni itp.

Nauczyciele, pedagodzy, trenerzy itp.

Za wyjątkiem pracowników gromadzących i analizujących dane oraz sporządzających sprawozdania.

8 Opiekunowie klientów, inżynierowie, naukowcy i pracownicy akademiccy, pracownicy obsługi prawnej itp.

Informatycy i programiści.

Artyści, projektanci, animatorzy, pracownicy mediów itp.

Architekci, kartografowie, robotnicy budowlani, instalatorzy, operatorzy dźwigów itp.

12 Sprzedawcy, pracownicy branży gastronomicznej, hotelarskiej, turystycznej, kosmetycznej itp.

13 Mechanicy specjaliści, serwisanci, ratownicy medyczni, konserwatorzy budynków, sprzątacze, robotnicy rolni itp.

14 Pracownicy działów finansowych, kadr, zamówień publicznych, obsługi administracyjnej itp.

15 Pracownicy produkcyjni, kierowcy i operatorzy urządzeń transportowych, operatorzy sprzętu rolniczego i urządzeń sortowniczych, pracownicy przygotowujący żywność, mechanicy ogólni itp.
} 
zawodowe mogą bowiem zostać zautomatyzowane stosunkowo najszybciej.

Narażonych na zaginięcie jest niewiele profesji, bo ok. 5\%, jednakże skutki automatyzacji będą odczuwalne niemalże w każdym zawodzie. Istniejące technologie są w stanie zautomatyzować 45\% czynności, za które ludzie pobierają wynagrodzenia, a przedstawiciele $60 \%$ zawodów już teraz dostrzegają, że $30 \%$ prac, które zwyczajowo wykonywali, zostało zautomatyzowanych [Chui et al., 2016]. W konsekwencji będzie to oznaczać, że przed koniecznością zmiany profesji w następstwie automatyzacji może stanąć nawet 75-375 mln ludzi na całym świecie [Manyika et al., 2017, s. 2]. Procesy te, jak zauważają E. Deskoska i J. Vlčková [2018, s. 50], spowodują m.in. tymczasowe bezrobocie technologiczne oraz spadek średniego dochodu, czego łącznym skutkiem będzie dalszy wzrost nierówności dochodowej. Dalekosiężnym skutkiem czwartej rewolucji przemysłowej ma być natomiast powstanie wielu nowych miejsc pracy w gospodarce światowej [Sun, 2018, s. 11].

Ważnym obszarem styku rewolucji przemysłowej i sektora ekonomii społecznej jest globalizacja cyfrowa gospodarki, której istotnym wymiarem jest likwidacja barier krajowych w handlu internetowym. Reakcją UE na ten proces jest Strategia jednolitego rynku cyfrowego, opierająca się na trzech filarach: (1) lepszym dostępie konsumentów i przedsiębiorstw do towarów i usług w Internecie w całej Europie, (2) tworzeniu odpowiednich warunków do rozwoju sieci i usług cyfrowych, oraz (3) maksymalizacji wzrostu gospodarczego generowanego przez europejską gospodarkę cyfrową. Realizacja Strategii ma doprowadzić m.in. do znacznego wzrostu wymiany transgranicznej, w której uczestniczy zalewie 7\% europejskich przedsiębiorstw sektora MŚP [Komisja Europejska, 2015, s. 3] oraz rozwoju badań naukowych i prac rozwojowych w ponad 800 obszarach zastosowań dzięki nowym superkomputerom [European Commission, 2018].

\section{Ekonomia społeczna u progu czwartej rewolucji przemysłowej}

Idea ekonomii społecznej nie jest monolityczna, a zbudowaniu jej spójnej definicji nie sprzyja wielość sposobów jej pojmowania i praktycznego stosowania w różnych krajach ${ }^{16}$. Na przykład w polskiej literaturze przedmiotu dostrzega się istnienie dwóch odrębnych nurtów rozważań o problematyce gospodarki społecznej - ekonomii społecznej i społecznej gospodarki rynkowej, które wprawdzie nie pokrywają się ze sobą, to jednak wiele je łączy. Z nurtu społecznej gospodarki rynkowej wypływa zasada, że gospodarka może być zarazem rynkowa, jak i społeczna, natomiast z rozważań prowadzonych na gruncie ekonomii społecznej wynika, że powinność zaspokajania celów społecznych przypisana jest, przede wszystkim, podmiotom przynależnym do szczególnego sektora gospodarki - ekonomii społecznej [Węsierska-Chyc, 2013, s. 9-10].

Ogłoszona w 2002 r. „Karta zasad ekonomii społecznej"17 wskazała na następujące zasady działalności w tym sektorze: (1) prymat celu indywidualnego i społecznego nad kapitałem; (2) dobrowolne i otwarte członkostwo; (3) demokratyczna kontrola przez członków; (4) powiązanie interesów członków bądź użytkowników z interesem społecznym; (5) ochrona i przestrzeganie zasad solidarności i odpowiedzialności; (6) autonomiczne zarządzanie i niezależność od władz publicznych, a także (7) przeznaczanie nadwyżki finansowej na cele zrównoważonego rozwoju, usługi dla członków lub potrzeby społeczne [Monzón, Chaves, 2012, s. 19].

W ostatnich latach definicja ekonomii społecznej w Europie stała się pojemniejsza. Poza

\footnotetext{
Pomimo uzasadnionych wątpliwości dotyczących poprawności stosowania określenia ekonomia społeczna jako polskiego odpowiednika terminu social economy, w artykule tym przyjęto utrwaloną w naszym kraju konwencję nazewniczą.

7 Kartę proklamowała Europejska Stała Konferencja Spółdzielni, Towarzystw Wzajemnościowych, Stowarzyszeń i Fundacji (CEP-CMAF), działająca na szczeblu Unii Europejskiej.
} 
tradycyjnymi organizacjami pozwala również zaliczać do tego sektora zupełnie nowe podmioty, o ile spełniają one określone kryteria organizacji wewnętrznej oraz celów działalności. Parlament Europejski w oficjalnym raporcie stwierdza, że ekonomia społeczna składa się z prywatnych inicjatyw społeczno-gospodarczych, które niezależnie od ich szczególnego statusu prawnego: (1) produkują dobra i usługi zarówno do celów rynkowych, jak i nierynkowych oraz redystrybuują i/lub reinwestują przychody i dochody; (2) opierają się na wartościach: trwałości, solidarności, zaufaniu, wzajemności, rozwoju lokalnym, spójności społecznej i integracji; oraz (3) mają na celu wzmocnienie spójności społecznej oraz świadomości i obywatelstwa poprzez współpracę wewnętrzną i zewnętrzną oraz wspólne działanie [Liger et al., 2016, s. 27].

Konsekwencją ewolucji rozumienia ekonomii społecznej w Europie jest pogłębianie się heterogeniczności układu podmiotowego tego sektora, a co za tym idzie - napędzanie procesów izomorfizacji sektorów rynkowego, publicznego i społecznego, prowadzących w przyszłości do całkowitego, być może, zatarcia granic między nimi.

W UE funkcjonuje około $2 \mathrm{mln}$ podmiotów ekonomii społecznej, czyli 10-12\% wszystkich europejskich przedsiębiorstw. W 2010 r. wąsko pojmowane podmioty ekonomii społecznej zatrudniały ponad 14,5 miliona osób, co stanowiło 6,5\% całej populacji aktywnej zawodowo w UE. W 2002 r. było to odpowiednio 11 milionów osób i 6,5\% ogółu zatrudnionych [ibidem, s. 8].

Podmioty ekonomii społecznej w UE prowadzą działalność w sektorach: usług pomocy społecznej (16,7\% ogółu podmiotów), usług zatrudnieniowych i szkoleniowych (14,9\%), ochrony środowiska (14,5\%), edukacyjnym $(14,5 \%)$, rozwoju społeczno-gospodarczego (14,3\%), kultury, sportu i rekreacji (7\%) oraz ochrony zdrowia (6,9\%) [Selusi Project, 2010]. Podobny obraz pokazują aktualniejsze, choć niereprezentatywne dla całej UE, badania ${ }^{18}$. Najwięcej organizacji zadeklarowało działalność w sektorach: usług pomocy społecznej (26\%), usług edukacyjnych i szkoleniowych $(21,1 \%)$, działalności związanej z zatrudnieniem (19,6\%), kultury i rekreacji (16,2\%), gospodarki odpadami (11,8\%), działalności profesjonalnej i doradczej $(8,1 \%)$, opieki zdrowotnej i usług medycznych $(7,8 \%)$ oraz sprzątania i konserwacji budynków $(6,1 \%)$. Co istotne, w sektorach przetwórstwa przemysłowego oraz budownictwa działalność prowadziło odpowiednio zaledwie 4,4\% i 3\% badanych organizacji ${ }^{19}$ [OECD, 2013, s. 25, 27-28]. Uwzględniając różnice pomiędzy zakresem sektorów działalności w obydwu badaniach, profil aktywności podmiotów ekonomii społecznej jest wyraźnie skoncentrowany w sferze szeroko pojmowanych usług społecznych.

Podmioty ekonomii społecznej w UE nie prowadzą działalności wyłącznie w granicach konkretnych sektorów działalności. Podejmują one zróżnicowane, także innowacyjne działania gospodarcze, jak np. tworzą sieci małych i średnich przedsiębiorstw w sektorze przetwórstwa przemysłowego. Wyniki badań przeprowadzonych w projekcie SELUSI pokazują, że odsetek organizacji, które wprowadziły na rynek nowe lub przełomowe innowacje w ciągu ostatnich lat jest znacznie wyższy wśród przedsiębiorstw społecznych niż wśród porównywalnych firm komercyjnych [Selusi Project, 2010].

Ważną miarą potencjału ekonomicznego podmiotów ekonomii społecznej jest liczba zatrudnionych w pełni wynagradzanych pracowników. W organizacjach objętych przytaczanym badaniem mediana tej liczby wyniosła

\footnotetext{
18 Badania te przeprowadzono w 2012 r. na próbie 655 organizacji w 13 regionach Australii, Belgii, Kanady, Francji, Włoch, Rumunii i Szwecji oraz w Luksemburgu

19 Mniej niż 6\% badanych organizacji zadeklarowało działalność w sektorach: rolnictwa, leśnictwa i rybołówstwa, turystyki (5,1\%), handlu hurtowego i detalicznego, administrowania osiedlami mieszkaniowymi, przetwórstwa przemysłowego, budownictwa, działalności finansowej i ubezpieczeniowej, zaopatrywania w energię i wodę i innych.
} 
10 osób [ibidem]. Z innych badań wynika ponadto, że wśród ogółu zatrudnionych w sektorze ekonomii społecznej przeważają kobiety, czego przyczyną jest wysoki udział miejsc pracy, które sektor ten oferuje w zawodach tradycyjnie wykonywanych przez kobiety [OECD, 2013, s. 22].

Źródła przychodów podmiotów ekonomii społecznej znacznie się różnią między krajami, a w przypadku organizacji zbadanych w projekcie były nimi: sprzedaż dóbr i usług (32\%), dotacje (31\%), zamówienia publiczne (15\%), darowizny i granty (11\%), opłaty członkowskie (7\%), inne źródła (4\%) [ibidem, s. 27].

Kompetencje podmiotów sektora ekonomii społecznej do aktywnego korzystania z technologii cyfrowych nie są w pełni rozpoznane, ale wyraźnie podkreśla się bariery strukturalne w tym sektorze w postaci niskich kompetencji kadr w tym zakresie oraz słabego poziomu przyswajania nowych technologii [Liger et al., 2016, s. 70, 82].

\section{Implikacje czwartej rewolucji przemysłowej dla sektora ekonomii społecznej}

Czwarta rewolucja przemysłowa stawia podmioty sektora ekonomii społecznej przed koniecznością sprostania wielu wyzwaniom, które przede wszystkim dotyczą: profilu działalności, skali i zakresu wytwarzanych produktów i usług, kierunków rozwoju działalności wytwórczej i usługowej, zatrudnienia i kwalifikacji pracowników, a także zakresu wykorzystania nowych technologii oraz aktywnego uczestnictwa w ich tworzeniu. W zależności od stopnia wdrożenia wymaganych zmian dostosowawczych, nakreślone zostaną trzy scenariusze prognozujące przyszłość sektora ekonomii społecznej - reaktywny, adaptacyjny i antycypacyjny.

\section{Scenariusz 1 - Reaktywny}

Pierwszy scenariusz zakłada, że podmioty sektora ekonomii społecznej nie skorzystają z szans, jakie stwarza czwarta rewolucja przemysłowa. W strukturze zatrudnienia podmiotów ekonomii społecznej dominują pracownicy z grup zawodowych wykonujących czynności w małym stopniu substytuowane przez roboty, a więc $\mathrm{w}$ niewielkim stopniu narażonych na utratę zatrudnienia. Tymczasowe bezrobocie technologiczne oraz pogłębianie się nierówności dochodowych wygenerują ponadto dodatkowy średniookresowy popyt na usługi tradycyjnie świadczone przez organizacje ekonomii społecznej - zatrudnieniowe, szkoleniowe, edukacyjne, w obszarze pomocy społecznej i doradztwie profesjonalnym (towarzystwa wzajemnościowe, organizacje oferujące usługi finansowe i eksperckie). Pierwszy scenariusz prognozuje zatem względną stabilność lub przyrost zatrudnienia w sektorze ekonomii społecznej oraz zakłada, że sektor ten będzie pełnił rolę bufora neutralizującego skutki zmian strukturalnych na rynku pracy - podobną do tej, jaką, zdaniem Ligera i współpracowników [2016, s. 60], pełnił on podczas ostatniego kryzysu finansowego.

Perspektywa utrzymania bądź wzrostu popytu na produkty i usługi oferowane przez podmioty ekonomii społecznej na obecnych zasadach skłoni je do kierowania się strategią doraźnych korzyści, ignorującej działania modernizacyjne. Zaniechanie rozwoju kompetencji pracowników i usługobiorców oraz nieprzyswajanie nowych technologii, np. ułatwiających transgraniczną wymianę produktów i usług, osłabi pozycję podmiotów sektora ekonomii społecznej względem konkurentów. W dłuższej perspektywie organizacje te będą narażone na regres rynkowy, spadek dochodów z tytułu sprzedaży produktów, usług i realizowanych zamówień publicznych oraz na konieczność sięgania po gwarantujące przetrwanie środki dotacyjne, darowizny i granty.

W scenariuszu reaktywnym podmioty ekonomii społecznej działające w sektorze przetwórstwa przemysłowego wypadną z rynku na skutek konkurencji ze strony przedsiębiorstw automatyzujących produkcję i wykorzystują- 
cych technologie cyfrowe w relacjach z klientami i kooperantami.

\section{Scenariusz 2 - Adaptacyjny}

Drugi scenariusz zakłada, że podmioty sektora ekonomii społecznej skorzystają z okna nowych możliwości i dokonają modernizacji, umożliwiającej im czynne uczestnictwo w procesach gospodarczych wynikających z czwartej rewolucji przemysłowej. Bezpośrednim celem unowocześniania będzie wdrażanie nowych technologii do procesów produkcyjnych, ich wykorzystanie dla rozwoju świadczonych usług oraz wdrażania nowych produktów i usług oraz ich personalizacji. Powodzenie tych zamierzeń jest warunkowane zwiększeniem kompetencji pracowników sektora ekonomii społecznej, zwłaszcza technologicznych i biznesowych, poprzez kształcenie ustawiczne oraz zatrudnianie nowych specjalistów.

W tym scenariuszu podmioty ekonomii społecznej wykorzystają instrumenty jednolitego rynku cyfrowego oraz uzyskają dostęp do transnarodowych rynków wymiany dóbr, usług, pracowników, kapitału i informacji.

Rozwój tanich platform cyfrowych otworzy nowe możliwości podmiotom ekonomii społecznej prowadzącym działalność związaną z zatrudnieniem. Szansą dla tych organizacji będzie wykorzystanie wzrostu liczby ofert pracy dystrybuowanych za pośrednictwem internetowych serwisów społecznościowych i platform tematycznych oraz inteligentnych technologii ułatwiających lepsze dopasowanie tych ofert do potrzeb pracodawców i pracowników. Internet nie wyeliminuje niezbędnych w tego rodzaju usługach spotkań bezpośrednich, ale przyczyni się do zwiększenia skuteczności świadczenia usług pośrednictwa pracy, poprawy trafności doboru pracowników i miejsc pracy oraz obniżenia łącznych kosztów świadczenia usług. Z kolei organizacje przykładowo wytwarzające wysokiej jakości produkty będą mogły je sprzedawać za pośrednictwem platform cyfrowych w innych krajach, a także naby- wać w ten sam sposób materiały i usługi niezbędne dla własnej działalności.

Poważną barierą dla podmiotów sektora ekonomii społecznej aspirujących do świadczenia usług na jednolitym rynku cyfrowym będzie istniejąca konkurencja na tym rynku. Podmiotom tym będzie niezwykle trudno rywalizować z dominującymi dostawcami usług na rynku cyfrowym, takimi jak Uber czy Airbnb, ze względu na popularność tych marek, czy też stosowane metody podziału pracy [Liger et al., 2016, s. 73].

Platformy cyfrowe oraz powszechny dostęp do Internetu stwarzają też podmiotom sektora ekonomii społecznej lepsze warunki dla rozwoju usług opartych na sieciach współpracy. Dotyczy to przede wszystkim rozwoju terytorialnego oraz usług świadczonych na odległość (m.in. edukacyjnych). Szerokie otwarcie się organizacji ekonomii społecznej na nowe technologie przyczyni się do zwiększania ich przychodów ze sprzedaży produktów i usług, a także darowizn celowych i ogólnych pozyskiwanych za pośrednictwem platform crowdfundingowych.

Szansę dla spółdzielni i innych podmiotów sektora ekonomii społecznej realizujących programy taniego budownictwa społecznego stanowi rozwój technologii druku 3D w budownictwie ${ }^{20}$.

Wiele możliwości rysuje się też przed podmiotami działającymi w sektorze opieki zdrowotnej i usług medycznych. Połączenie sztucznej inteligencji z metodami analizowania dużych zbiorów danych polepszy trafność diagnostyki medycznej (wykrywanie nowotworów, chorób serca, choroby Alzheimera, rzadkich chorób genetycznych itd.) oraz umożliwi projektowanie w pełni spersonalizowanych algorytmów leczenia. Placówki lecznicze i opiekuńcze, które zamiast długotrwałej i kosztownej walki z chorobami zaoferują leczenie umożliwiające godne życie z przewlekłą cho-

20 Pierwszy budynek w tej technologii powstał w 2015 r. w Holandii. 
robą, staną się liderami zmian technologicznych w całym sektorze ekonomii społecznej.

\section{Scenariusz 3 - Antycypacyjny}

Trzeci scenariusz zakłada, że sektor ekonomii społecznej przyjmie rolę aktywnego uczestnika procesów antycypacji zmian społecznych oraz współtwórcy rozwiązań technologicznych o zasięgu lokalnym, jak i globalnym, a także rozwiązań instytucjonalnych i polityk publicznych wspomagających postęp czwartej rewolucji przemysłowej oraz łagodzących jej skutki.

Realizacja tego scenariusza zakłada konieczność znacznego zwiększenia kompetencji pracowników sektora ekonomii społecznej o kluczowe kompetencje przyszłości. Należą do nich: umiejętność rozwiązywania problemów złożonych, kompetencje społeczne ${ }^{21}$, procesowe ${ }^{22}$, systemowe ${ }^{23}$ i zdolności poznaw$\mathrm{CZe}^{24}$ [WEF, 2016].

Zaangażowanie podmiotów sektora ekonomii społecznej w projektowanie rozwiązań technologicznych, instytucjonalnych i polityk publicznych będzie szczególnie pożądane w obszarze nowych form i instrumentów: edukacyjnych i szkoleniowych, reintegracji społecznej, działalności zatrudnieniowej, pomocy społecznej, działalności kulturalnej, naukowej, rozwoju terytorialnego, rozwoju miast i obszarów wiejskich w tym procesów marginalizacji i gentryfikacji, ochrony środowiska, produkcji i dystrybucji żywności, a także świadczenia usług doradczych i finansowych dla sektora społecznego.

W obszarze działalności edukacyjnej i szkoleniowej podmioty sektora ekonomii społecznej mogłyby pełnić rolę ośrodków kształcenia w zakresie doskonalenia kompetencji przyszłości, a zwłaszcza kompeten-

\footnotetext{
${ }^{21}$ Umiejętności perswazyjne, uczenia innych, inteligencja emocjonalna itp.

22 Uważne słuchanie i krytyczne myślenie itp.

23 Analizowanie kosztów i korzyści, relacji organizacji z otoczeniem, ewaluacja działalności itp.

${ }^{24}$ Kreatywność i rozumowanie itp.
}

cji społecznych i procesowych, zdolności poznawczych, a także kompetencji technicznych - w obszarach działalności sektora społecznego i obywatelskiego. W warunkach czwartej rewolucji przemysłowej oferta edukacyjna i szkoleniowa w powyższym zakresie powinna być oferowana każdej grupie wiekowej i na każdym poziomie kształcenia. Potrzeby gospodarki, usieciowienie i cyfryzacja rynków edukacyjnych, stworzą warunki do współtworzenia produktów edukacyjnych przez różne typy podmiotów (naukowe, biznesowe, administracyjne, społeczne) oraz kształcenia na odległość. Wbrew niektórym stanowiskom [Eberhard et al., 2017, s. 48], odpowiedzialność za kształcenie dla przyszłości nie będzie spoczywać wyłącznie na instytucjach edukacyjnych.

Scenariusz antycypacyjny powinien także uwzględniać nową przestrzeń dla sektora ekonomii społecznej w sferze badań naukowych i kształtowaniu polityk publicznych. Nauka i polityka publiczna zawsze były blisko ze sobą powiązane, a powstanie i rozwój nauk o polityce publicznej oraz krzewienie idei trzeciej misji uniwersytetu więzi te utrwalają. W warunkach czwartej rewolucji przemysłowej sektor ekonomii społecznej powinien czynniej niż dotychczas włączać się w badania naukowe i projektowanie polityk publicznych. Aktywność ta może, z jednej strony, polegać na uczestnictwie w projektach badawczych konsorcjów naukowych i naukowo-przemysłowych, z drugiej zaś na pracach nad wizją technologii kształtowania polityk publicznych w ramach czwartej rewolucji przemysłowej. W tym kontekście istotne będzie wypracowanie metod analizowania, projektowania i ewaluacji polityk publicznych odpowiadających zmianie społecznej oraz wykorzystujących nowe możliwości technologiczne (analizy na dużych zbiorach danych, sensory i superkomputery, uczące się maszyny itd.).

W scenariuszu antycypacyjnym metody działania sektora ekonomii społecznej zostaną głęboko zredefiniowane, a wykorzystywane 
przez podmioty ekonomii społecznej technologie i kompetencje pracowników zasadniczo nie będą odbiegać od tych, które będą w posiadaniu przedsiębiorstw rynkowych.

\section{Podsumowanie}

Czwarta rewolucja przemysłowa tworzy wiele możliwości dla podmiotów ekonomii społecznej. W zależności od zrealizowanych

\section{Literatura}

Baldassari P., Roux J.D. (2017). „Industry 4.0: Preparing for the Future of Work", People and Strategy, vol. 40, iss. 3, Summer, s. 20-23.

Brekelmans M. (2016). „Industry 4.0 will disrupt existing markets and usher in change", China Bussiness Review, July 8, https://www.chinabusinessreview. com/industry-4-0-will-disrupt-existing-marketsand-usher-in-change/.

Buhr D. (2015). Social Innovation Policy for Industry 4.0. Bonn: Friedrich-Ebert-Stiftung.

Chui M., Manyika J., Miremadi M. (2016). „Where machines could replace humans - and where they can't (yet)", McKinsey Quarterly, June, http://www. mckinsey.com/business-functions/digital-mckinsey/our-insights/where-machines-could-replacehumans-and-where-they-cant-yet.

Csath M. (2018). "Competitiveness Based on Knowledge and Innovation Possibilities of Increasing Budget Revenues in the Era of Digitalisation and Robotisation", Public Finance Quarterly, no 1, s. 64-79. Deskoska E., VIčková J. (2018). „The Role of Technological Change in Income Inequality in the United States", Acta Oeconomica Pragensia, nr 26(1), s. 47-66.

Drath R., Horch A. (2014). "Industrie 4.0: Hit or Hype?", IEEE Industrial Electronics Magazine, nr 8(2), s. 56-58.

Eberhard B. (2017). "Smart work: The transformation of the labour market due to the fourth industrial revolution (14.0)", International Journal of Business and Economic Sciences Applied Research, vol. 10(3), s. 47-66.

European Commission (2018). Council backs Commission's plans to invest $€ 1$ billion in world-class European supercomputers. Press release IP/18/5864, 28 September. Brussels, http://europa.eu/rapid/pressrelease_IP-18-5864_en.htm.

Komisja Europejska (2015). Strategia jednolitego rynku cyfrowego dla Europy. Komunikat Komisji do Parlamentu Europejskiego, Rady, Europejskiego Komitetu scenariuszy, sektor ten w długim okresie czasu zostanie technologicznie i rynkowo zmarginalizowany (scenariusz reaktywny), będzie beneficjentem zachodzących zmian (scenariusz adaptacyjny) bądź stanie się aktywnym współtwórcą nowych projektów społecznych, gospodarczych i systemowych (scenariusz antycypacyjny). Realizacja określonych scenariuszy będzie miała wpływ na przyszłość poszczególnych organizacji ekonomii społecznej, jak i całego sektora.

Ekonomiczno-Społecznego i Komitetu Regionów, 6.5.2015, COM(2015) 192 final. Bruksela.

Kuruczleki É., Pelle A., Laczi R., Fekete B. (2016). "The Readiness of the European Union to Embrace the Fourth Industrial Revolution", Management, nr 11(4), s. 327-347.

Liao Y., Deschamps F., Loures E., Ramos L. (2017). „Past, present and future of Industry 4.0 - a system"Ptic literature review and research agenda proposal", International Journal of Production Research, vol. 55, no. 12, s. 3609-3629.

Liger Q., Stefan M., Britton J. (2016). Social Economy: Study. Brussels: Directorate-General for Internal Policies, European Parliament.

Maynard A. (2015). "Navigating the fourth industrial revolution", Nature Nanotechnology, nr 10(12), s 1005-1006.

Manyika J., Lund S., Chui M., Bughin J., Woetzel J., Batra P., Ko R., Sanghvi S. (2017). Jobs Lost, Jobs Gained: Workforce Transitions In A Time Of Automation. San Francisco: McKinsey Global Institute.

Monzón J., Chaves R. (2012). The European Social Economy. Brussel: European Economic and Social Committee.

OECD (2013). Job Creation Through the Social Economy and Social Entrepreneurship. Programme on Local Economic and Employment Development. Paris: OECD Publishing.

Selusi Project (2010). Social Enterprises, Worth a Closer Look. Early Insights, Issue 7, Fourth Quarter.

Sun M. (2018). The Impacts of the Fourth Industrial Revolution on Jobs and the Future of the Third Sector. NICVA, http://www.nicva.org/sites/default/files/ d7content/attachments-articles/the_impact_of_ the_4th_industrial_revolution_on_jobs_and_the_ sector.pdf.

WEF (2016). The Future of Jobs: Employment, Skills and Workforce Strategy for the Fourth Industrial Revolution. Geneva: World Economic Forum, http://www3.weforum.org/docs/WEF_Future_of_Jobs.pdf. 
Węsierska-Chyc L. (2013). „Gospodarka społeczna to nie sektor", Ekonomia Społeczna, nr 3(8), s. 9-23.

\section{Adjustment scenarios of the social economy sector to the realities of the fourth industrial revolution}

Summary: The 4th Industrial Revolution causes profound changes in every sector of the economy and in society. Its effects will also be felt by social economy entities. The aim of the article is to sketch scenarios determining the degree of adaptation of the social economy entities in Europe to the technological changes taking place as part of the 4th Industrial Revolution. On the basis of literature studies and the heuristic scenario method, three adaptation scenarios of social economy entities to new realities were formulated - reactive, adaptive and anticipating. The implementation of specific scenarios will affect the future of every social economy entity as well as the entire sector.

Keywords: 4th Industrial Revolution, social economy, development scenarios, public policy.

\section{Prawa autorskie i licencja / Copyright and License}

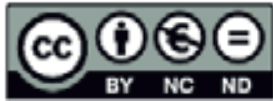

Artykuł opublikowano na licencji Creative Commons Uznanie autorstwa - Użycie niekomercyjne - Bez utworów zależnych 3.0 Polska http://creativecommons.org/licenses/by-nc-nd/3.0/pl/

This article is published under the terms of the Creative Commons Attribution - NonCommercial - NoDerivs (CC BY-NCND 3.0) License http://creativecommons.org/licenses/by-nc-nd/3.0/ 